\title{
17 $\beta$-estradiol down-regulates lipopolysaccharide-induced MCP-1 production and cell migration in vascular smooth muscle cells
}

\author{
Ping Jiang ${ }^{*}$ Jinwen $\mathrm{Xu}^{*}$, Shuhui Zheng, Jinghe Huang, Qiuling Xiang, \\ Xiaodong Fu and Tinghuai Wang
}

Department of Physiology, Zhongshan School of Medicine, Sun Yat-sen University, Guangdong, Guangzhou 510089, People's Republic of China

(Correspondence should be addressed to T Wang; Email: wangth@mail.sysu.edu.cn)

*(P Jiang and $\mathrm{J}$ Xu contributed equally to this work)

\begin{abstract}
Atherosclerosis is an inflammatory disease where lipopolysaccharide (LPS) triggers the release of inflammatory cytokines that accelerate its initiation and progression. Estrogen has been proven to be vasoprotective against atherosclerosis; however, the anti-inflammatory function of estrogen in the vascular system remains obscure. In this study, we investigated the effect of estrogen on LPS-induced monocyte chemoattractant protein-1 (MCP-1; listed as CCL2 in the MGI database) production in vascular smooth muscle cells (VSMCs). LPS significantly enhances MCP-1 production and this is dependent on nuclear factor $\kappa B(N F \kappa B)$ signaling, since the use of NF $\mathrm{B}$ inhibitor pyrrolidine dithiocarbamate or the silencing of $N F \kappa B$ subunit p65 expression with specific siRNA largely impairs LPS-enhanced MCP-1 production. On the contrary, $17 \beta$-estradiol $\left(E_{2}\right)$ inhibits LPS-induced MCP-1 production in a time- and dosedependent manner, which is related to the suppression of p65 translocation to nucleus. Furthermore, p38 MAPK is rapidly activated in response to LPS, while $E_{2}$ markedly inhibits p38 MAPK activation. Transfection with p38 MAPK siRNA or the use of p38 MAPK inhibitor SB203580 markedly attenuates LPS-stimulated p65 translocation to nucleus and MCP-1 production, suggesting that $E_{2}$ suppresses NFKB signaling by the inactivation of p38 MAPK signaling. LPS promotes VSMCs migration and this is abrogated by MCP-1 antibody, implying that MCP-1 may play a major role as an autocrine factor in atherosclerosis. In addition, $\mathrm{E}_{2}$ inhibits LPS-promoted cell migration by downregulation of MCP-1 production. Overall, our results demonstrate that $\mathrm{E}_{2}$ exerts anti-inflammatory property antagonistic to LPS in VSMCs by reducing MCP-1 production, and this effect is related to the inhibition of $\mathrm{p} 38 \mathrm{MAPK} / \mathrm{NF} \kappa \mathrm{B}$ cascade.
\end{abstract}

Journal of Molecular Endocrinology (2010) 45, 87-97

\section{Introduction}

Atherosclerosis is an inflammatory disease (Ross 1999). It is characterized by the formation of atherosclerotic plaques where cellular immune response takes place. Bacterial peptidoglycans, chlamydiae, or viruses have been found in the atherosclerotic lesions (Laman $e t$ al. 2002, Liu et al. 2006). Among these etiological factors, lipopolysaccharide (LPS), an outer-membrane component of Gram-negative bacteria, is the most important one responsible for vascular inflammation (Lehr et al. 2001, Kiechl et al. 2002). In fact, LPS even at low levels constitutes a strong risk factor for the development of atherosclerosis (Wiedermann et al. 1999), and it constitutes the trigger for events related to a possible link between periodontitis and atherosclerosis (Hettne et al. 2007). Similarly, in rat models, chronic exposure to LPS leads to atherosclerotic lesions in arteries (Smith et al. 2009). By binding its central signaling receptor Toll-like receptor 4, LPS activates a cluster of cells, including monocytes, macrophages, lymphocytes, vascular endothelial cells (VECs), and vascular smooth muscle cells (VSMCs; Galkina \& Ley 2009). These cells then produce a variety of inflammatory cytokines, which are responsible for the initiation and acceleration of atherosclerotic lesions (Liao 1996, Loppnow et al. 2008).

Monocyte chemoattractant protein-1 (MCP-1; listed as CCL2 in the MGI database), a member of the CC chemokine family, is one of the inflammatory cytokines that can be produced by VECs and VSMCs in response to LPS (Yang et al. 2005, Anand et al. 2009). The deleterious effects of this cytokine in the cardiovascular system have been demonstrated in MCP-1 or MCP-1 receptor CCR2 knockout mice, with those mice developing smaller atherosclerotic lesions (Boring et al. 1998, Gu et al. 1998). In contrast, mice overexpressing MCP-1 had larger lesions (Aiello et al. 1999). The mechanisms underlying the pro-atherogenic effects of MCP-1 are complex. One crucial mechanism is that MCP-1 recruits and enhances VSMC migration towards subendothelial area, thus accelerating the progression 
of atherosclerosis (Spinetti et al. 2004, Ma et al. 2007). In this regard, it has been reported that LPS is able to simulate VSMCs migration (Lin et al. 2007). These observations highlight the possibility that MCP-1 may act as an important mediator in LPS-induced cell migration.

Hormone replacement therapy (HRT) is believed to induce cardiovascular protection (Mendelsohn \& Karas 1999), while clinical trials have challenged this assumption (Rossouw et al. 2002). Recently, the Women's Health Initiative subgroup analysis suggested that HRT is still effective to reduce cardiovascular risk in young postmenopausal women (Rossouw et al. 2007). The cardiovascular protective effects of estrogen are largely attributed to its direct actions on vasculature $(\mathrm{Fu}$ \& Simoncini 2007). Currently, it is well recognized that estrogen functions as an immunomodulator in the cardiovascular system. It exerts anti-inflammatory effects on the vasculature through different mechanisms. On the other hand, estrogen also elicits pro-inflammatory changes under certain conditions (Chakrabarti et al. 2008). Estrogen has been shown to antagonize LPS-induced inflammatory responses in several organ systems, such as brain (Pozzi et al. 2006), lung (Speyer et al. 2005), and vasculature (Corbacho et al. 2007, Liu et al. 2009). Nevertheless, the intrinsic mechanisms of how estrogen acts as an anti-inflammatory agent against LPS still need to be elucidated. In the present study, we investigated the inhibitory effect of estrogen on LPS-stimulated VSMCs migration and the role of MCP-1 in this effect. In particular, the signaling events recruited by estrogen receptors (ERs) were characterized.

\section{Materials and methods}

\section{Cell cultures and treatments}

\section{Cell culture}

VSMCs were isolated from rat thoracic aorta (female Sprague-Dawley, 6-10 weeks old, provided by the Animal Center of Sun Yat-sen University; Certificate number: SCSK (Yue) 2008-2009/0034) by enzymatic dispersion and cultured over several passages. Cells were grown in a $5 \% \quad \mathrm{CO}_{2}$ atmosphere at $37^{\circ} \mathrm{C}$ in DMEM without phenol, and supplemented with penicillin and streptomycin, and $10 \%$ fetal bovine serum charcoal was stripped (steroid free and delipidated, FCS; Biowest, S181F-500, Nuaillé, France). Experiments were performed with cells from passages 5 to 10 . Before experiments, cells were kept in phenol red-free DMEM containing 1\% FBS for $48 \mathrm{~h}$. Cultures were pretreated with different concentrations of $17 \beta$-estradiol $\left(\mathrm{E}_{2} ;\right.$ Sigma) for the indicated times and subsequently stimulated with Escherichia coli LPS
(Sigma) for another $24 \mathrm{~h}$. Whenever an inhibitor was used, the compound was added 30 min before starting the treatments. SB203580, pyrrolidine dithiocarbamate (PDTC), pertussis toxin (PTX), and wortmannin (WM) were purchased from Sigma-Aldrich. 4,4',4"-(4-propyl[1H]-pyrazole-1,3,5-triyl) trisphenol (PPT), 2,3-bis(4-hydroxyphenyl)-propionitrile (DPN), and ICI 182780 were purchased from Tocris Cookson (Bristol, UK).

\section{Immunoblottings}

Cell lysates were separated by SDS-PAGE. Antibodies used were as follows: p38 MAPK and phospho-p38 MAPK (9210; Cell Signaling, Danvers, MA, USA), actin (sc-1615; Santa Cruz Biotechnology, Santa Cruz, CA,

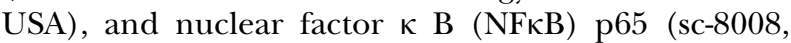
Santa Cruz). Primary and secondary antibodies were incubated with the membranes by standard technique. Immunodetection was accomplished using enhanced chemiluminescence. Chemiluminescence was acquired with a quantitative digital imaging system (Quantity One, Bio-Rad) allowing to check for saturation. Overall emitted photons were quantified for each band, particularly for loading controls, which were homogeneously loaded.

\section{ELISA for MCP-1 protein}

MCP-1 concentrations in culture medium were measured using an ELISA kit (KRC1011, BioSource, Invitrogen Corporation) according to the manufacturer's instructions. In brief, cells in 24-well plates were serum deprived at $70 \%$ confluence. After treatments, media supernatants were collected and centrifuged at $9000 \mathrm{~g}$ (10 000 r.p.m.) for $1 \mathrm{~min}$. The supernatants were stored at $-80{ }^{\circ} \mathrm{C}$ until the assay. Experiments were performed in quadruplicate and verified on at least two occasions. Results were expressed as total supernatant MCP-1 per milligram cell protein (mean \pm S.D).

\section{Cell immunofluorescence}

VSMCs were grown on coverslips. After treatment, cells were fixed with $4 \%$ paraformaldehyde for $30 \mathrm{~min}$ and permeabilized with $0 \cdot 1 \%$ Triton $\mathrm{X}$ for 5 min. Blocking was performed with 3\% BSA for $30 \mathrm{~min}$. Cells were incubated with NFאB p65 antibody (sc-8008, Santa Cruz) at $4{ }^{\circ} \mathrm{C}$ overnight. After washing, a FITCconjugated secondary antibody (K00018968; Dako North America Inc., Dako, Carpinteria, CA, USA) was used for $1 \mathrm{~h}$ at room temperature. The nuclei were counterstained with 4'-6-diamidino-2-phenylindole (Sigma). Cells were mounted with fluorescence mounting medium (10027230, Dako) and covered with a coverslip. Samples were analyzed with Olympus fluoview FV1000 confocal microscope. 


\section{Transfection experiments and luciferase reporter assay}

On-TARGETplus SMARTpool siRNA reagents against rat p38 MAPK $\alpha(\mathrm{NM}-031020)$ and control siRNA (D-001810-01-05) were purchased from Dharmacon (Thermo Fisher Scientific Inc., San Jose, CA, USA). p65 siRNA (antisense 5'-AAGAGCATCATGAAGAAGAGTCCTGTCTC-3', sense 5'-AAACTCTTCTTCATGATGCTCCCTGTCTC- ${ }^{\prime}$ ) was designed by Riobio (Riobio Biotech Corporation, Guangzhou, China) according to a previous report (Lianxu et al. 2006). VSMCs were transfected with siRNA using Lipofectamine (Invitrogen) according to the protocol. Cells (40\% confluent) were serum-starved for $1 \mathrm{~h}$, followed by incubation with $100 \mathrm{nM}$ target siRNA or control siRNA for $6 \mathrm{~h}$ in serum-free media. The serumcontaining media were then added ( $10 \%$ serum final concentration) for $42 \mathrm{~h}$ before experiments, and/or functional assays were conducted. Target protein silencing was assessed through protein analysis up to $48 \mathrm{~h}$ after transfection.
$\mathrm{NF} \kappa \mathrm{B}$ transient transfection assays have been reported previously (Wu et al. 2008). The cells were transfected using the SuperFect reagent (Qiagen) with a NFкB luciferase reporter plasmid (Clontech) and a SV40 promoter-driven $\beta$-galactosidase expression plasmid to normalize the transfection efficiency. Twentyfour hours later, the culture medium was replaced, and cells were pretreated with $\mathrm{E}_{2}$ for $12 \mathrm{~h}$ following by stimulation with LPS. After $24 \mathrm{~h}$, the cells were lysed, and the luciferase activity was measured according to the manufacturer's instruction using a luminometer.

\section{Cell migration assays and transwell experiments}

Adherent cells $\left(2 \times 10^{5}\right)$ were scraped off from the bottom of a culture plate using a pipette tip to create a cell-free (wounded) area. The cell culture was washed with PBS to remove cell debris, and then $2 \mathrm{ml}$ of DMEM containing steroid-deprived FBS and gelatin $(1 \mathrm{mg} / \mathrm{ml})$ were added. Cells were incubated with LPS alone or in combination with $\mathrm{E}_{2}$ for $48 \mathrm{~h}$, and migration was
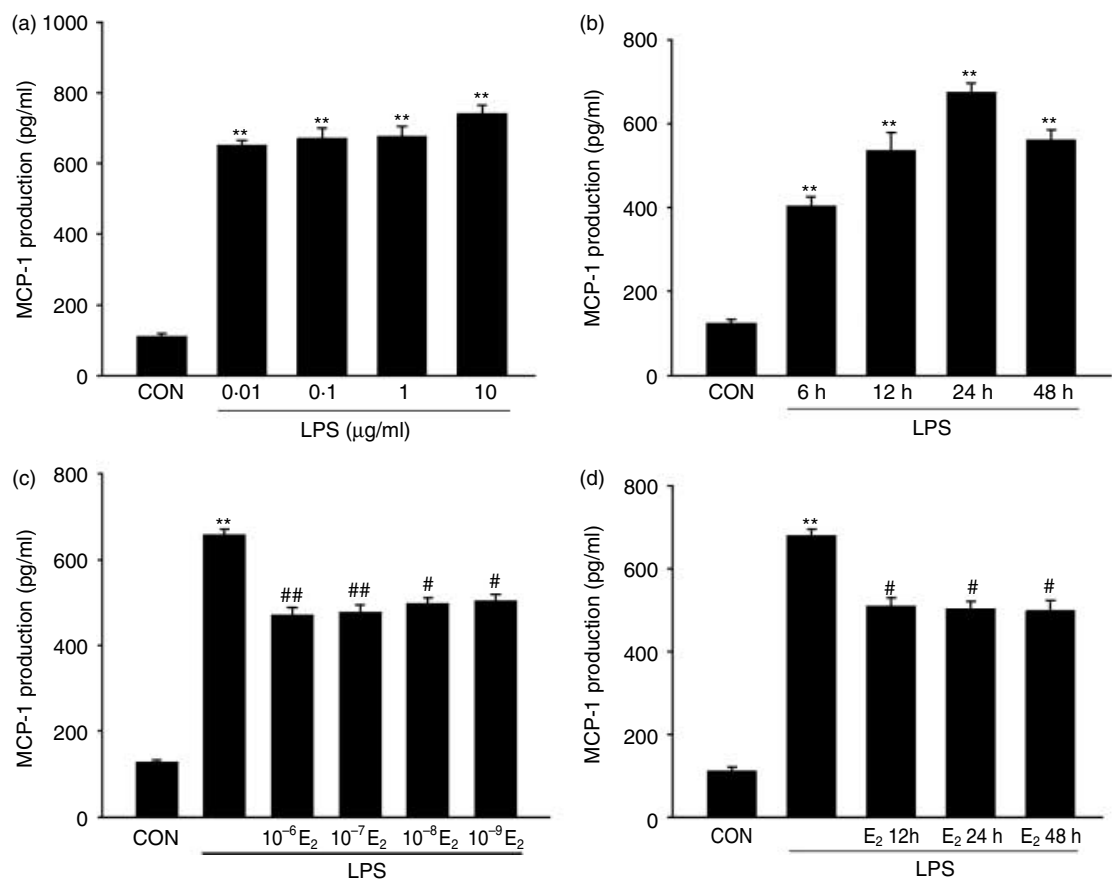

Figure 1 LPS enhanced MCP-1 production in VSMCs. (a) VSMCs were exposed to increasing concentrations of LPS $(0 \cdot 01-10 \mu \mathrm{g} / \mathrm{ml})$ for $24 \mathrm{~h}$, and MCP-1 level was measured using ELISA. ** $P<0.01$ versus control. (b) MCP-1 production was enhanced by treating with LPS $(0.1 \mu \mathrm{g} / \mathrm{ml})$ for the indicated times. ${ }^{\star \star} P<0.01$ versus control. (c) VSMCs were pretreated with various concentrations of $E_{2}\left(10^{-9}-10^{-6} \mathrm{~mol} / \mathrm{l}\right)$ for $24 \mathrm{~h}$, and subsequently stimulated with $0.1 \mu \mathrm{g} / \mathrm{ml}$ LPS for another $24 \mathrm{~h}$. Then MCP-1 production was measured. ${ }^{\star \star} P<0.01$ versus control; ${ }^{\#} P<0.05$ versus LPS group. ${ }^{\# \#} P<0.01$ versus LPS group.

(d) VSMCs were pretreated with $E_{2}\left(10^{-8} \mathrm{~mol} / \mathrm{l}\right)$ for different times, and subsequently stimulated with $0.1 \mu \mathrm{g} / \mathrm{ml}$ LPS for another $24 \mathrm{~h}$. MCP-1 production was measured. ${ }^{\star *} P<0.01$ versus control; ${ }^{\#} P<0.05$ versus LPS group. Each experiment was performed in quadruplicate and verified on at least two occasions. Results were expressed as total supernatant MCP-1 per milligram cell protein (mean \pm S.D). 
monitored. Fresh medium and treatment were replaced for every $12 \mathrm{~h}$. Cells were digitally imaged, and migration distance was measured by using phasecontrast microscopy.

Transwell experiments were performed as previously described ( Jiang et al. 2010). In brief, cells were seeded into the upper chamber of the transwell chamber (Corning Life Sciences, Lowell, MA, USA). After incubation with LPS alone or in combination with $\mathrm{E}_{2}$, cells that had invaded to the lower surface of the membranes were fixed with methanol for $10 \mathrm{~min}$ and stained with hematoxylin. The cells on the lower side of the membrane were counted and averaged in six high-power fields $(200 \times)$ with a light microscope.

\section{Statistical analysis}

All values are expressed as mean \pm s.D. Statistical differences between mean values were determined by ANOVA, followed by the Fisher's protected least significance difference test. All differences were considered significant at $P<0 \cdot 05$.

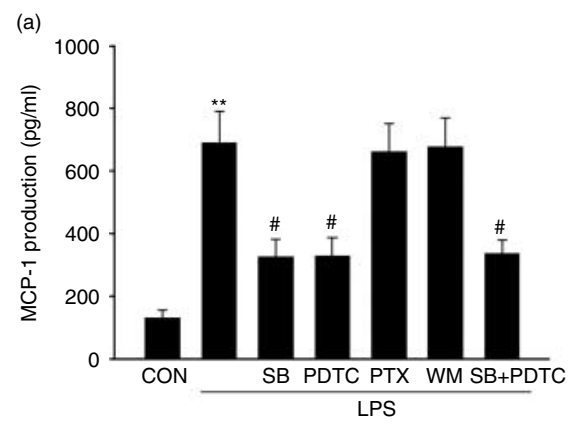

(b)

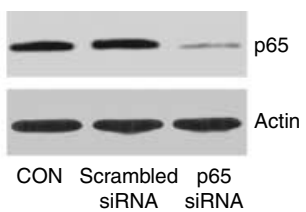

(d)
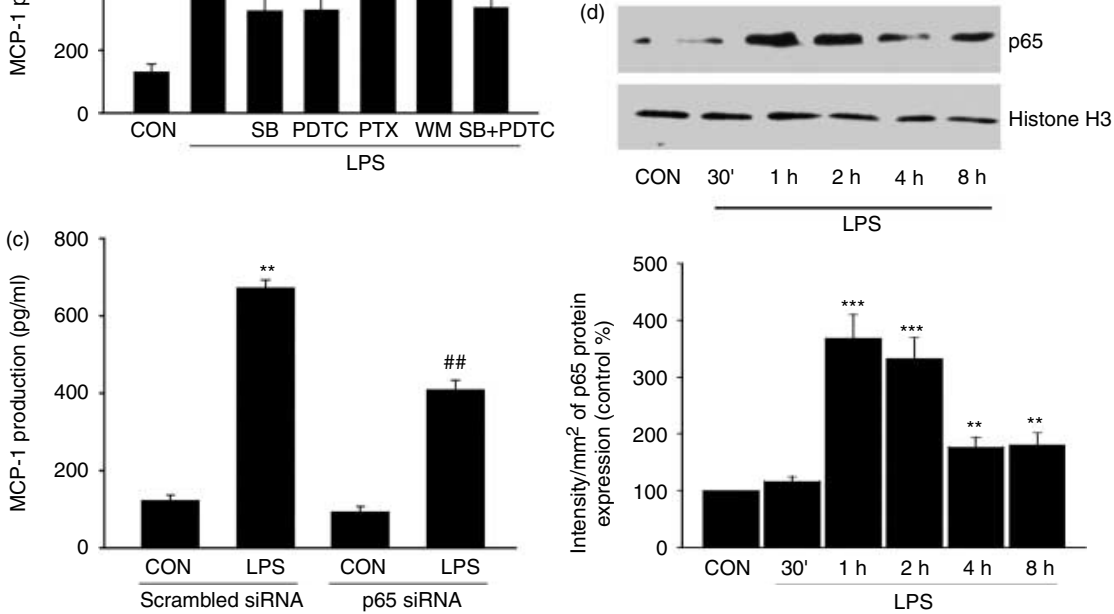

(e)
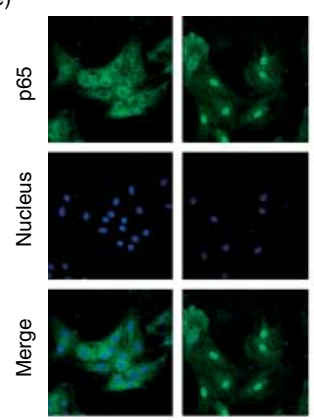

LPS

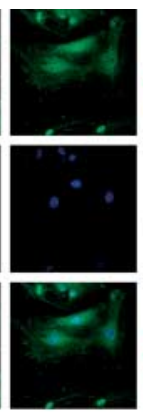

$\mathrm{LPS}+\mathrm{E}_{2}$

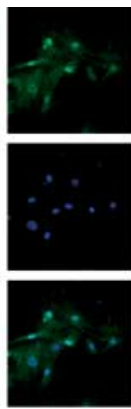

LPS+SB (g)

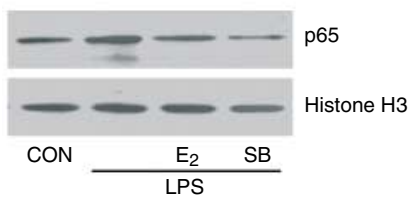

(f)
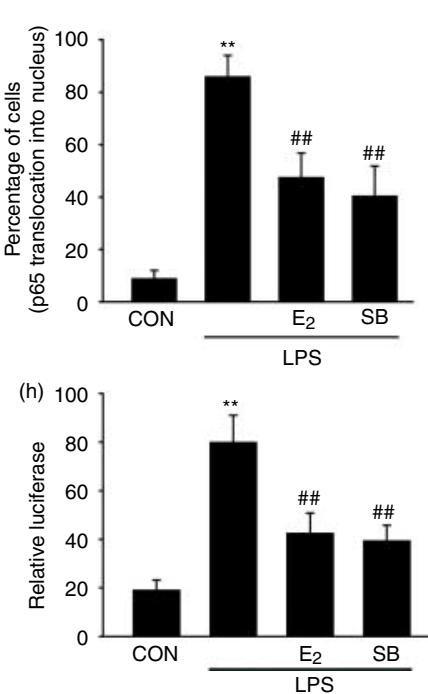


\section{Results}

\section{$E_{2}$ inhibited LPS-induced MCP-1 production in VSMCs}

VSMCs were exposed to increasing concentration of LPS $(0 \cdot 01-10 \mu \mathrm{g} / \mathrm{ml})$ for $24 \mathrm{~h}$, and the MCP-1 production was measured by using ELISA. Consistent with data from others (Yang et al. 2005), LPS induced MCP-1 production in a concentration-dependent manner, with maximal effect at $10 \mu \mathrm{g} / \mathrm{ml}$ (Fig. 1a). In order to avoid cytotoxic effect, we used a relatively low dose of $0 \cdot 1 \mu \mathrm{g} / \mathrm{ml}$ LPS as the optimal concentration to assess the time course. As shown in Fig. 1b, MCP-1 production was elevated within $6 \mathrm{~h}$ after LPS $(0 \cdot 1 \mu \mathrm{g} / \mathrm{ml})$ treatment, and was maximal at $24 \mathrm{~h}$.

To investigate the anti-inflammatory role of $\mathrm{E}_{2}$, VSMCs were pretreated with various concentrations of $\mathrm{E}_{2}\left(10^{-9}-10^{-6} \mathrm{M}\right)$ for $24 \mathrm{~h}$, followed by the stimulation with $0 \cdot 1 \mu \mathrm{g} / \mathrm{ml}$ LPS for another $24 \mathrm{~h}$. Pretreatment with different concentrations of $\mathrm{E}_{2}$ all caused a significant decrease in LPS-induced MCP-1 production (Fig. 1c). In addition, LPS-induced MCP-1 production was markedly inhibited by pretreatment with $10^{-8} \mathrm{M} \mathrm{E}_{2}$ for $12 \mathrm{~h}$, and this inhibitory effect reached a plateau between 24 and $48 \mathrm{~h}$ (Fig. 1d).

\section{$E_{2}$ reduced MCP-1 production via the inactivation of NFKB signaling}

To characterize the intracellular events implicated in LPS action, we utilized several signaling cascade inhibitors relevant to TRL4 signalings. The blockade of p38 MAPK activity with SB203580 at $20 \mu \mathrm{M}$, the concentration widely used in other similar studies (Fatima et al. 2001, Gorlach et al. 2001), largely reduced MCP-1 production (Fig. 2a). Likewise, the $\mathrm{NF \kappa B}$ pathway inhibitor PDTC also led to a marked reduction of MCP-1 production (Fig. 2a). However, no additive effect was found when both inhibitors were used together (Fig. 2a). On the contrary, neither the G protein inhibitor PTX nor the phosphatidylinositol-3 $\mathrm{OH}$ kinase inhibitor WM altered LPS-induced MCP-1 production (Fig. 2a). These results suggested that p38 MAPK and NFKB pathways may be involved in LPSstimulated MCP-1 production.

To confirm the role of NFKB pathway in LPS-induced MCP-1 production, we silenced NFкB subunit p65 expression by using specific siRNA (Fig. 2b). As a result, the silencing of p65 markedly impaired LPS-induced MCP-1 production (Fig. 2c). Indeed, challenge with LPS enhanced nuclear NFKB subunit p65 expression as early as $30 \mathrm{~min}$, and the LPS increase reached the maximum at $1 \mathrm{~h}$ (Fig. 2d). This was further confirmed by confocal microscopy showing that while cells are in a quiescent state, $\mathrm{p} 65$ protein was mainly located in cytoplasm and only $8 \%$ of total cells showed a strongly positive nuclear stain, whereas under LPS stimulation, p65 protein translocated from cytoplasm into nucleus, with $85 \%$ of cells positively stained (Fig. 2e and f).

Moreover, to determine whether LPS increases transcriptional activation of $\mathrm{NF} \kappa \mathrm{B}-$ dependent gene expression, we employed an $\mathrm{NF} \kappa \mathrm{B}$ promoter luciferase construct. LPS induced approximately a fourfold increase in $\mathrm{NF} \kappa \mathrm{B}$ promoter-driven luciferase activity (Fig. 2h). On the contrary, the p38 MAPK inhibitor SB203580 efficiently prevented p65 nuclear translocation and luciferase activity (Fig. 2e-h), implying that p38 MAPK is indispensable for NFкB activation.

Pretreatment with $10^{-8} \mathrm{M} \mathrm{E}_{2}$ for $24 \mathrm{~h}$ reversed the LPS-evoked p65 expression and reduced the nuclear translocation of p65 in VSMCs (Fig. 2e-g). It also reduced LPS-stimulated luciferase activity (Fig. 2h). Together, these results indicate that $\mathrm{E}_{2}$ reduces MCP-1 production through the inactivation of NFKB signaling.

\footnotetext{
Figure $2 \mathrm{E}_{2}$ inhibited LPS-induced MCP-1 production through suppression of NFKB pathway. (a) VSMCs were exposed to $0 \cdot 1 \mu \mathrm{g} / \mathrm{ml} \mathrm{LPS}$

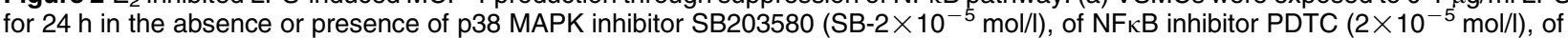
G protein inhibitor pertussis toxin (PTX, $100 \mathrm{ng} / \mathrm{ml}$ ), and of PI3K inhibitor wortmannin (WM-30 nmol/l). MCP-1 production was measured. ${ }^{* *} P<0.01$ versus control; ${ }^{\#} P<0.05$ versus LPS group. (b) VSMCs were transfected with scrambled siRNA or p65-targeted siRNAs for $48 \mathrm{~h}$. After that, the level of 055 protein expression was detected by western blot. Actin was used as a loading control. (c) VSMCs were transfected with scrambled siRNA or p65-targeted siRNAs for $48 \mathrm{~h}$. Then, cells were exposed to $0.1 \mu \mathrm{g} / \mathrm{ml} \mathrm{LPS} \mathrm{for} 24 \mathrm{~h}$, and MCP-1 production was measured. ${ }^{\star \star} P<0.01$ versus corresponding control; ${ }^{\# \#} P<0.01$ versus corresponding control. (d) VSMCs were exposed to $0.1 \mu \mathrm{g} / \mathrm{ml}$ LPS for different times as indicated. Cell nucleus was extracted, and p65 protein expression was detected by western blot. Nuclear marker histone $\mathrm{H} 3$ was used as a loading control. p65 densitometry values were adjusted to histone $\mathrm{H} 2$ intensity, and then normalized to expression from the control sample. ${ }^{\star \star \star} P<0.001$ versus control; ${ }^{\star \star} P<0.01$ versus control. (e) VSMCs were exposed to $0.1 \mu \mathrm{g} / \mathrm{ml}$ LPS for $1 \mathrm{~h}$ with or without pretreatment with $\mathrm{E}_{2}\left(10^{-8} \mathrm{~mol} / \mathrm{l}\right)$ or SB203580 (SB-2 $\left.\times 10^{-5} \mathrm{~mol} / \mathrm{l}\right)$ for $24 \mathrm{~h}$. Subcellular localization of the p65 NFкB subunit was assayed with cell immunofluorescence technique. VSMCs were stained with an antibody versus p65 (FITC; green staining), and nuclei were counterstained with DAPI (blue staining). (f) Cells were counted in six different fields, and the percentage of cells with p65 nuclear staining was expressed as means \pm s.D. ${ }^{* \star} P<0.01$ versus control; ${ }^{\# \#} P<0.01$ versus LPS. (g) VSMCs were treated as indicated. Cell nucleus was extracted, and p65 protein expression was detected by western blot. (h) VSMCs were transfected with NFKB promoter luciferase construct, and then treated for $12 \mathrm{~h}$ with $\mathrm{E}_{2}\left(10^{-8} \mathrm{~mol} / \mathrm{l}\right)$, followed by stimulation with $0 \cdot 1 \mu \mathrm{g} / \mathrm{ml} \mathrm{LPS}$ for $24 \mathrm{~h}$. After that, the NFKB reporter was measured and normalized to $\beta$-galactosidase activity. Values shown represent the mean \pm s.D. of triplicate experiments. ${ }^{\star *} P<0.01$ versus control; ${ }^{\# \#} P<0.01$ versus LPS.
} 
(a)

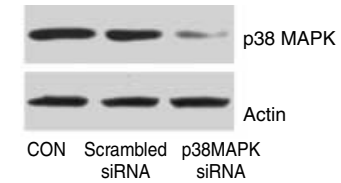

(b)
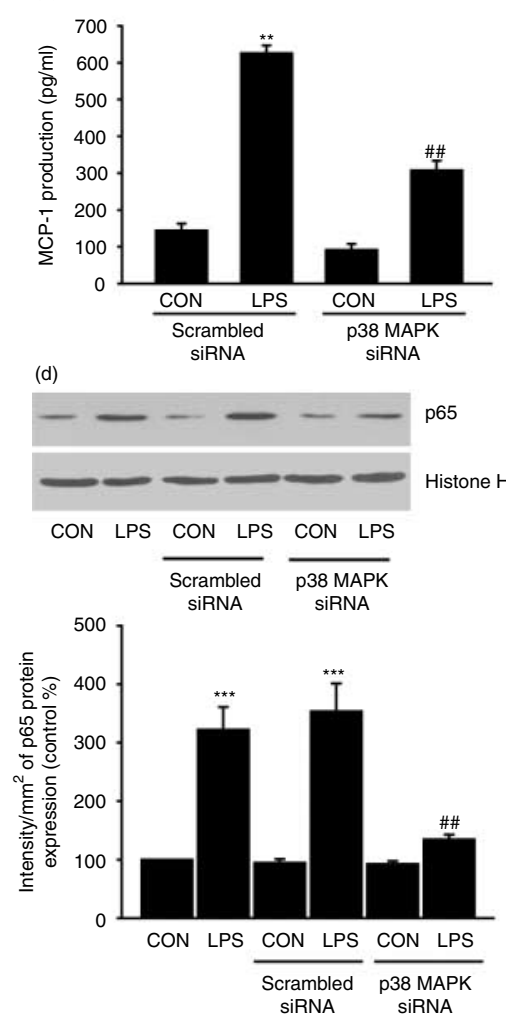

(f)
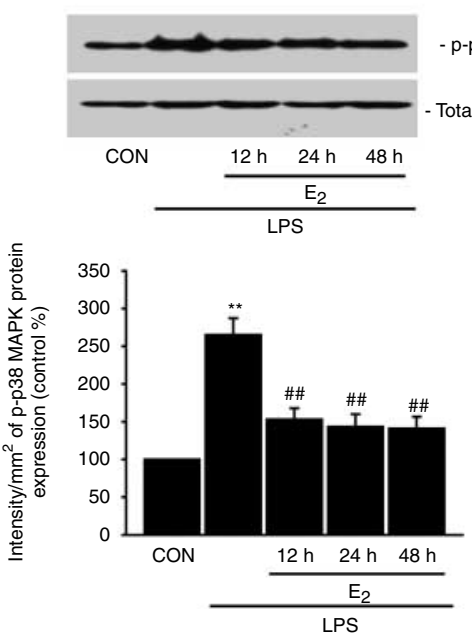

p65

Histone $\mathrm{H} 3$ (c)

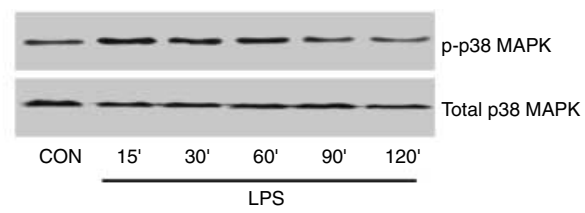

(e)
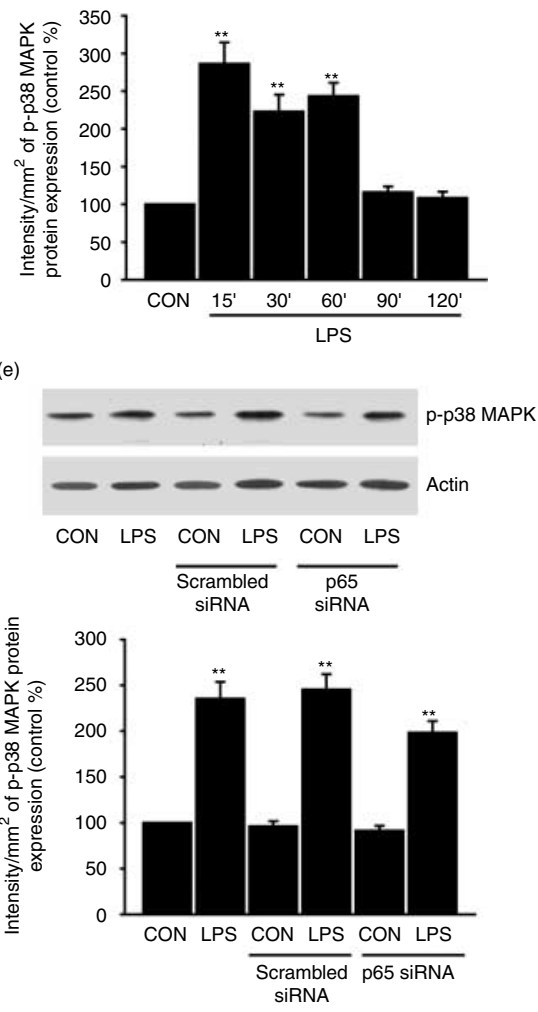

(g)
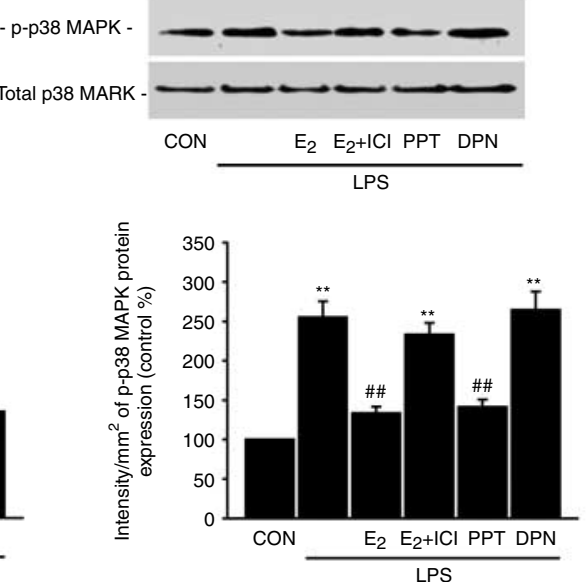


\section{$E_{2}$ suppressed $N F \kappa B$ cascade via the dephosphorylation of p38 MAPK pathway}

We further checked the role of p38 MAPK in LPSrecruited signalings. By using specific siRNA for p38 MAPK, we silenced its expression in VSMCs (Fig. 3a). As a consequence, the silencing of p38 MAPK significantly reduced MCP-1 production induced by LPS (Fig. 3b). In addition, LPS resulted in a rapid increase of p38 MAPK phosphorylation (Fig. 3c). These data indicate that p38 MAPK is activated by LPS and is responsible for MCP-1 production.

To clarify the relevance between p38 MAPK and the $\mathrm{NF} \kappa \mathrm{B}$ cascade, we silenced their expression by using specific siRNA. LPS-induced p65 expression in the nucleus was prevented in p38 MAPK siRNA-transfected VSCMs compared with control (Fig. 3d), while the silencing of p65 expression did not alter LPS effect on p38 MAPK phosphorylation (Fig. 3e). These findings imply that p38 MAPK functions as the upstream of NFKB cascade.

Pretreatment with $10^{-8} \mathrm{M} \mathrm{E}_{2}$ for 12,24 , and $48 \mathrm{~h}$ all decreased LPS-stimulated p38 MAPK phosphorylation (Fig. 3f). This inhibitory effect was mimicked by the $\mathrm{ER} \alpha$ (ESR1) agonist PPT, but not by the ER $\beta$ (ESR2) agonist DPN (Fig. 3g). Moreover, the inhibitory effect of $\mathrm{E}_{2}$ on $\mathrm{p} 38$ MAPK phosphorylation was prevented by ER antagonist ICI 182780 (Fig. 3g).

\section{$E_{2}$ inhibited LPS-provoked VSMCs migration via the downregulation of MCP-1 production}

Finally, we explored the roles of LPS and $\mathrm{E}_{2}$ in VSMCs migration by using wound assay and by the modified Boyden chamber assay. Exposure of VSMCs to LPS significantly enhanced VSMCs migration distance and migrating cell numbers, which was significantly inhibited by pretreatment with $\mathrm{E}_{2}$ (Fig. 4a-d). Meanwhile, MCP-1 antibody largely reduced LPS-enhanced cell migration distance and numbers of migrating cells into the membrane (Fig. 4a-d). MCP-1 antibody or $\mathrm{E}_{2}$ use alone did not display a significant effect on cell migration (Fig. 4a-d).

\section{Discussion}

Estrogen deters atherosclerosis in healthy women, but the exact mechanism is still a matter of investigation. Previously, we and others have demonstrated that estrogen induces vasodilatation, and regulates vascular cell growth and migration as well as protects cardiomyocytes from injury (Simoncini et al. 2006, Fu et al. 2007, Liu et al. 2007, Kublickiene et al. 2008). The present study reveals that estrogen exerts anti-inflammatory activity in VSMCs by reducing LPS-induced MCP-1 production, thus inhibiting cell migration. These salutary effects may converge into a protective action of estrogen on the vessels from atherosclerotic lesions.

Atherosclerosis is an inflammatory disease, and estrogen may function as an anti-inflammatory factor (Chakrabarti et al. 2008). Indeed, menopause and ovariectomy generate a low grade of systemic inflammation, which can be reversed by the administration of estrogen (Abu-Taha et al. 2009). This may be related to the regulatory effects of estrogen on the production of inflammatory cytokines (Georgiadou \& Sbarouni 2009). For instance, an in vivo study showed that transdermal estrogen therapy reduces circulating levels of several cytokines, including MCP-1 (Yasui et al. 2009). In parallel, studies in vitro demonstrate that estrogen reduces MCP-1 production in several cells, such as peripheral blood mononuclear cells and immature dendritic cells (Bengtsson et al. 2004, Yuan et al. 2008). The present study provides the first evidence that estrogen directly acts on VSMCs by decreasing LPS-stimulated MCP-1 production, which adds new insight into estrogen's anti-inflammatory functions in cardiovascular system.

Figure $3 \mathrm{E}_{2}$ suppressed NFKB cascade via the dephoshorylation of p38 MAPK pathway. (a) VSMCs were transfected with scrambled siRNA or p38 MAPK-targeted siRNAs for $48 \mathrm{~h}$. After that, the level of p38 MAPK protein expression was detected by western blot. (b) VSMCs were transfected with scrambled siRNA or p38 MAPK-targeted siRNAs for $48 \mathrm{~h}$. Then, cells were exposed to $0.1 \mu \mathrm{g} / \mathrm{ml}$ LPS for $24 \mathrm{~h}$, and MCP-1 production was measured. ${ }^{\star \star} P<0.01$ versus corresponding control; ${ }^{\# \#} P<0.01$ versus corresponding control. (c) VSMCs were exposed to $0.1 \mu \mathrm{g} / \mathrm{ml}$ LPS for different times, and phosphorylated p38 MAPK (p-p38 MAPK) protein expression was detected by western blot. p-p38 MAPK densitometry values were adjusted to total p38 MAPK intensity, and then normalized to expression from the control sample. ${ }^{\star *} P<0.01$ versus control. (d) VSMCs were transfected with scrambled siRNA or p38 MAPK-targeted siRNAs for $48 \mathrm{~h}$. Then, cells were exposed to $0.1 \mu \mathrm{g} / \mathrm{ml}$ LPS for $1 \mathrm{~h}$, and nuclear content of p65 expression was detected. p65 densitometry values were adjusted to histone $\mathrm{H} 3$ intensity, and then normalized to expression from the control sample. ${ }^{\star \star \star} P<0.001$ versus control; ${ }^{\# \#} P<0.01$ versus LPS treatment without transfection. (e) VSMCs were transfected with scrambled siRNA or p65-targeted siRNAs for $48 \mathrm{~h}$. Then, cells were exposed to $0.1 \mu \mathrm{g} / \mathrm{ml}$ LPS for $15 \mathrm{~min}$, and p-p38 MAPK expression was detected. p-p38 MAPK densitometry values were adjusted to actin intensity, and then normalized to expression from the control sample. ${ }^{* \star} P<0.01$ versus control. (f) VSMCs were pretreated with $E_{2}\left(10^{-8} \mathrm{~mol} / \mathrm{l}\right)$ for different times, and subsequently stimulated with $0 \cdot 1 \mu \mathrm{g} / \mathrm{ml} \mathrm{LPS}$ for 15 min. Cells were lysed, and p-p38 MAPK expression was detected. p-p38 MAPK densitometry values were adjusted to total p38 MAPK intensity, and then normalized to expression from the control sample. ${ }^{\star \star} P<0.01$ versus control; ${ }^{\# \#} P<0.01$ versus LPS. (g) VSMCs were pretreated with $\mathrm{E}_{2}\left(10^{-8} \mathrm{~mol} / \mathrm{l}\right)$ alone or in combination with ICl $182780\left(10^{-6} \mathrm{~mol} / \mathrm{l}\right)$, PPT $\left(10^{-8} \mathrm{~mol} / \mathrm{l}\right)$, and DPN $\left(10^{-8} \mathrm{~mol} / \mathrm{l}\right)$ for $24 \mathrm{~h}$, and subsequently stimulated with $0.1 \mu \mathrm{g} / \mathrm{ml}$ LPS for $15 \mathrm{~min}$. Cells were lysed, and p-p38 MAPK expression was detected. ${ }^{\star \star} P<0.01$ versus control; ${ }^{\# \#} P<0.01$ versus LPS. 
(a)
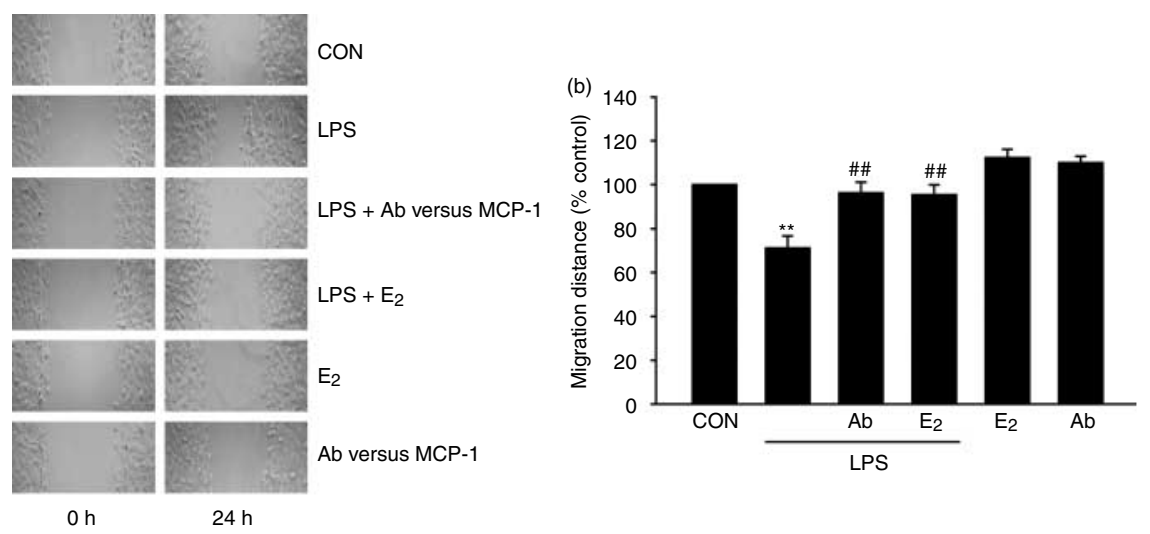

(c)

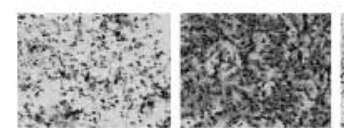

CON
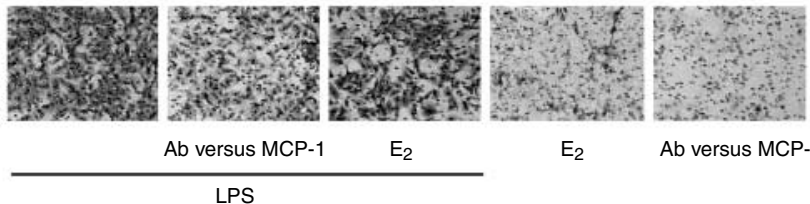

$\mathrm{E}_{2}$

Ab versus $M C P-1$

(d)

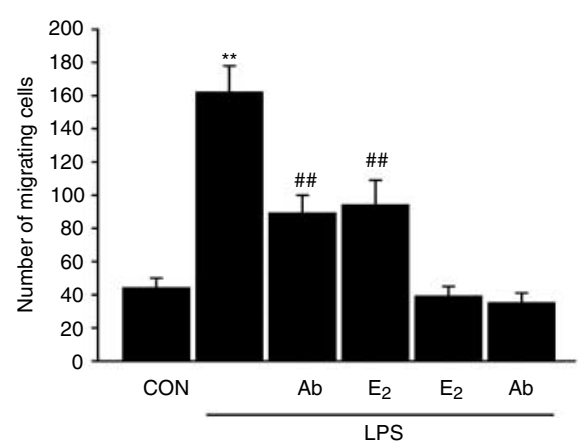

Figure $4 \mathrm{E}_{2}$ inhibited LPS-provoked VSMCs migration via the downregulation of MCP-1 production. (a) Adherent VSMCs were scrapped to create a cell-free (wounded) area. Then, cells were incubated with $0.1 \mu \mathrm{g} / \mathrm{ml}$ LPS alone or in combination with $E_{2}\left(10^{-8} \mathrm{~mol} / \mathrm{l}\right)$ or with antibody against MCP-1 (Ab versus MCP-1 - 1:100 dilution) for $48 \mathrm{~h}$, and migration was monitored. Cells were digitally imaged, and migration distance was measured by using phasecontrast microscopy. Representative images of cell migration are shown. (b) Cell migration distances were measured, and values are presented as $\%$ of control. ${ }^{* *} P<0.01$ versus control; ${ }^{\# \#} P<0.01$ versus LPS group. (c) After incubation with $0.1 \mu \mathrm{g} / \mathrm{ml}$ LPS alone or in combination with $E_{2}\left(10^{-8} \mathrm{~mol} / \mathrm{l}\right)$ or with antibody against MCP-1 (Ab versus MCP-1 - 1:100 dilution) for $48 \mathrm{~h}$, cells that had invaded to the lower surface of the membranes were fixed with methanol for $10 \mathrm{~min}$, and then stained with hematoxylin. Representative images of transwell experiments are shown. (d) The cells on the lower side of the membrane were counted and averaged in six high-power fields $(200 \times)$ with a light microscope. ${ }^{\star \star} P<0.01$ versus control; ${ }^{\# \#} P<0.01$ versus LPS group.

The migration of VSMCs from arterial media to intima is an essential step in the pathogenesis of atherosclerosis. It has been reported that LPS promotes VSMCs migration, but the mechanism remains unclear (Lin et al. 2007). Our data show that LPS promotes VSMCs migration, which is markedly inhibited by MCP-1 antibody, indicating that MCP-1 is an important mediator for LPS action. On the other side, $\mathrm{E}_{2}$ inhibits LPS-induced VSMCs migration, and this is possibly related to the decreased MCP-1 production. MCP-1 belongs to the member of the CC chemokine family. It is expressed by various non-immune cells, including VECs and VSMCs (Charo \& Taubman 2004). Elevated levels of MCP-1 are observed in atherosclerotic plaques, and mice overexpressing MCP-1 develops larger atherosclerotic lesions (Aiello et al. 1999). Currently, the role of MCP-1 in atherosclerosis is predominantly explained by its ability to recruit macrophages and monocytes to 
the vessel wall (Harrington 2000). Apart from that, here we demonstrate that MCP-1 directly drives VSMCs migration. In parallel, MCP-1 can also be produced by VECs, and recruits VSMCs migration towards endothelium (Ma et al. 2007). Therefore, MCP-1 may function as a potent stimulator for VSMCs migration in both autocrine and paracrine manner. Notwithstanding, the detailed molecular basis for MCP-1's effect on cell migration is still lacking. In this regard, our previous work has demonstrated that actin cytoskeleton remodeling is an essential step for cell migration (Fu et al. 2008), and it could be modulated by MCP-1 (Lee et al. 2009). These observations hint at the possibility that MCP-1 may induce actin cytoskeleton rearrangement in VSMCs. This, however, is beyond the scope of the present work and will be investigated in future studies.

Our data show that during challenge with LPS, NFאB subunit p65 translocates into the nucleus. $\mathrm{NF} \kappa \mathrm{B}$ is linked to the development of numerous inflammatory disorders, including atherosclerosis. It is a heterodimeric protein composed of five different proteins ( $\mathrm{p} 50$, p52, p65/RelA, RelB, and c-Rel). These dimers exist in the cytoplasm in inactive forms that bound to the inhibitory protein I $\mathrm{B}$ (Hayden \& Ghosh 2004). Various activating agents can mediate the dissociation of $\mathrm{I} \kappa \mathrm{B}$ from NFKB and thus translocation of the p65 subunit into the nucleus, where it activates transcription of target genes (Hayden \& Ghosh 2004). Correspondingly, analysis of the promoter region of the human MCP-1 gene demonstrates the binding site for $\mathrm{NF \kappa B}$ (Rovin et al. 1995), and NFKB activation has been shown to upregulate MCP-1 production in VSMCs (Wang et al. 2000, Esteban et al. 2005). In line with these, we show that LPS enhances NFкB subunit p65 translocation into nucleus, and promotes NFKB promoter-driven luciferase activity. Moreover, the silencing of p65 markedly impairs MCP-1 production. These findings indicate that $\mathrm{NF} \kappa \mathrm{B}$ pathway is responsible for MCP-1 production induced by LPS.

Pretreatment with $\mathrm{E}_{2}$ reverses p65 nuclear translocation and $\mathrm{NF \kappa B}$ promoter-driven luciferase activity, implying that $\mathrm{E}_{2}$ may inhibit MCP-1 expression through the inactivation of $\mathrm{NF} \kappa \mathrm{B}$ signaling. In support of our findings, it has been shown that p65 nuclear translocation can be prevented by $\mathrm{E}_{2}$ in VECs, macrophages, and breast cancer cells (Hsu et al. 2000, Ghisletti et al. 2005, Tiruppathi et al. 2008). Currently, little is known about the $\mathrm{NF} \kappa \mathrm{B}$ transport machinery. In this aspect, it has been reported that dynein-dependent transport may be a conserved mechanism in $\mathrm{NF} \kappa \mathrm{B}$ activation (Shrum et al. 2009). Intriguingly, ER is shown to interact with dynein light chain and regulate its functions (den Hollander \& Kumar 2006). Thus, future studies will be needed to address the role of dynein in estrogen's inhibitory effect on NFKB signaling. p38 MAPK is one of the three major MAPK signaling pathways that participate in inflammatory response (Kyriakis \& Avruch 2001, Kaminska 2005). Our study demonstrates that p38 MAPK is rapidly phosphorylated in response to LPS. Silencing of p38 MAPK markedly inhibits LPS-induced p65 translocation to nucleus, leading to decreased MCP-1 production. These results imply that p38 MAPK functions as the critical upstream signal for $\mathrm{NF \kappa B}$. Likewise, it has been demonstrated that NF $\kappa \mathrm{B}$ activity is dependent on p38 MAPK activation in other types of cells (Baeza-Raja \& Munoz-Canoves 2004, Ryan et al. 2007). The exact mechanism of p38 MAPK-induced NFKB activation in VSMCs is poorly understood, and it may be relevant to the effects of p38 MAPK on $\mathrm{I} \kappa \mathrm{B}$ degradation or p65 transactivation (Baeza-Raja \& Munoz-Canoves 2004). p38 MAPK has been verified as the primary determinant of CCL2 transcription, the gene that encodes MCP-1 protein (Lu et al. 2009). Therefore, we do not exclude the possibility that p38 MAPK itself translocates into nucleus and regulates the $M C P-1$ gene, resulting in enhanced MCP-1 production in response to inflammatory stimuli.

We show that $\mathrm{E}_{2}$ inhibits LPS-induced p38 MAPK activation in a dose- and time-dependent manner, suggesting that $\mathrm{E}_{2}$ exerts anti-inflammatory activity by suppression of this pathway. The biological actions of $\mathrm{E}_{2}$ in the inflammatory response require the participation of specific receptor, namely $\mathrm{ER} \alpha$ or ER $\beta$. By using the ER-selective ligands PPT and DPN, we demonstrate that $\mathrm{ER} \alpha$ is necessary for p38 MAPK inhibition in VSMCs. These data are consistent with the previous reports showing that ER $\alpha$ is indispensable to estrogen's immune protective effects (Liu et al. 2003, Polanczyk et al. 2003, Vegeto et al. 2003). In contrast, several studies have reported that ER $\beta$ mediates estrogen's actions in inflammation (Baker et al. 2004, Xing et al. 2007). The cause of this discrepancy is still not well defined, and maybe related to the different cell types and the stimuli used in experimental settings.

Taken together, our findings demonstrate that $\mathrm{E}_{2}$ inhibits LPS-stimulated VSMCs migration by reducing MCP-1 production. This effect is related to the inhibition of the p38 MAPK/NFKB signaling cascade, and $E R \alpha$ appears to be the dominant ER subtype in these events. The characterization of the novel mechanism of $\mathrm{E}_{2}$ action may help to develop new pharmacological tools for the prevention of inflammatory response in cardiovascular system.

\section{Declaration of interest}

The authors declare that there is no conflict of interest that could be perceived as prejudicing the impartiality of the research reported. 


\section{Funding}

This work was supported by Administration of Chinese Traditional Medicine of Guangdong (No: 3060013).

\section{Author contributions statement}

$\mathrm{P}$ Jiang and $\mathrm{J} \mathrm{Xu}$ designed and carried out the experiments, analyzed the data, drafted, and revised the manuscript; S Zheng, J Huang, and $\mathrm{Q}$ Xiang carried out the experiments; X Fu reviewed and revised the manuscript; $\mathrm{T}$ Wang designed the experiments, analyzed the data, drafted, and revised the manuscript. All authors read and approved the final manuscript.

\section{References}

Abu-Taha M, Rius C, Hermenegildo C, Noguera I, Cerda-Nicolas JM, Issekutz AC, Jose PJ, Cortijo J, Morcillo EJ \& Sanz MJ 2009 Menopause and ovariectomy cause a low grade of systemic inflammation that may be prevented by chronic treatment with low doses of estrogen or losartan. Journal of Immunology 183 1393-1402.

Aiello RJ, Bourassa PA, Lindsey S, Weng W, Natoli E, Rollins BJ \& Milos PM 1999 Monocyte chemoattractant protein-1 accelerates atherosclerosis in apolipoprotein E-deficient mice. Arteriosclerosis, Thrombosis, and Vascular Biology 19 1518-1525.

Anand AR, Bradley R \& Ganju RK 2009 LPS-induced MCP-1 expression in human microvascular endothelial cells is mediated by the tyrosine kinase, Pyk2 via the p38 MAPK/NF-kappaB-dependent pathway. Molecular Immunology 46 962-968.

Baeza-Raja B \& Munoz-Canoves P 2004 p38 MAPK-induced nuclear factor-kappaB activity is required for skeletal muscle differentiation: role of interleukin-6. Molecular Biology of the Cell 15 2013-2026.

Baker AE, Brautigam VM \& Watters JJ 2004 Estrogen modulates microglial inflammatory mediator production via interactions with estrogen receptor beta. Endocrinology 145 5021-5032.

Bengtsson AK, Ryan EJ, Giordano D, Magaletti DM \& Clark EA 2004 17beta-estradiol $\left(\mathrm{E}_{2}\right)$ modulates cytokine and chemokine expression in human monocyte-derived dendritic cells. Blood 104 1404-1410.

Boring L, Gosling J, Cleary M \& Charo IF 1998 Decreased lesion formation in CCR2 $-/-$ mice reveals a role for chemokines in the initiation of atherosclerosis. Nature 394 894-897.

Chakrabarti S, Lekontseva O \& Davidge ST 2008 Estrogen is a modulator of vascular inflammation. IUBMB Life 60 376-382.

Charo IF \& Taubman MB 2004 Chemokines in the pathogenesis of vascular disease. Circulation Research 95 858-866.

Corbacho AM, Eiserich JP, Zuniga LA, Valacchi G \& Villablanca AC 2007 Compromised aortic vasoreactivity in male estrogen receptoralpha-deficient mice during acute lipopolysaccharide-induced inflammation. Endocrinology 148 1403-1411.

Esteban V, Ruperez M, Sanchez-Lopez E, Rodriguez-Vita J, Lorenzo O, Demaegdt H, Vanderheyden P, Egido J \& Ruiz-Ortega M 2005 Angiotensin IV activates the nuclear transcription factor-kappaB and related proinflammatory genes in vascular smooth muscle cells. Circulation Research 96 965-973.

Fatima S, Khandekar Z, Parmentier JH \& Malik KU 2001 Cytosolic phospholipase A2 activation by the p38 kinase inhibitor SB203580 in rabbit aortic smooth muscle cells. Journal of Pharmacology and Experimental Therapeutics 298 331-338.

Fu XD \& Simoncini T 2007 Non-genomic sex steroid actions in the vascular system. Seminars in Reproductive Medicine 25 178-186.

Fu XD, Cui YH, Lin GP \& Wang TH 2007 Non-genomic effects of 17 betaestradiol in activation of the ERK1/ERK2 pathway induces cell proliferation through upregulation of cyclin D1 expression in bovine artery endothelial cells. Gynecological Endocrinology 23 131-137.
Fu XD, Giretti MS, Baldacci C, Garibaldi S, Flamini M, Sanchez AM, Gadducci A, Genazzani AR \& Simoncini T 2008 Extra-nuclear signaling of progesterone receptor to breast cancer cell movement and invasion through the actin cytoskeleton. PLoS ONE 3 e2790.

Galkina E \& Ley K 2009 Immune and inflammatory mechanisms of atherosclerosis (*). Annual Review of Immunology 27 165-197.

Georgiadou P \& Sbarouni E 2009 Effect of hormone replacement therapy on inflammatory biomarkers. Advances in Clinical Chemistry 47 59-93.

Ghisletti S, Meda C, Maggi A \& Vegeto E 2005 17beta-estradiol inhibits inflammatory gene expression by controlling NF-kappaB intracellular localization. Molecular and Cellular Biology 25 2957-2968.

Gorlach A, Diebold I, Schini-Kerth VB, Berchner-Pfannschmidt U, Roth U, Brandes RP, Kietzmann T \& Busse R 2001 Thrombin activates the hypoxia-inducible factor-1 signaling pathway in vascular smooth muscle cells: role of the p22(phox)-containing NADPH oxidase. Circulation Research 89 47-54.

Gu L, Okada Y, Clinton SK, Gerard C, Sukhova GK, Libby P \& Rollins BJ 1998 Absence of monocyte chemoattractant protein-1 reduces atherosclerosis in low density lipoprotein receptor-deficient mice. Molecular Cell 2 275-281.

Harrington JR 2000 The role of MCP-1 in atherosclerosis. Stem Cells 18 $65-66$.

Hayden MS \& Ghosh S 2004 Signaling to NF-kappaB. Genes and Development 18 2195-2224.

Hettne KM, Weeber M, Laine ML, ten Cate H, Boyer S, Kors JA \& Loos BG 2007 Automatic mining of the literature to generate new hypotheses for the possible link between periodontitis and atherosclerosis: lipopolysaccharide as a case study. Journal of Clinical Periodontology 34 1016-1024.

den Hollander P \& Kumar R 2006 Dynein light chain 1 contributes to cell cycle progression by increasing cyclin-dependent kinase 2 activity in estrogen-stimulated cells. Cancer Research 66 5941-5949.

Hsu SM, Chen YC \& Jiang MC 200017 beta-estradiol inhibits tumor necrosis factor-alpha-induced nuclear factor-kappa B activation by increasing nuclear factor-kappa B p105 level in MCF-7 breast cancer cells. Biochemical and Biophysical Research Communications 279 47-52.

Jiang X, Zhang Y, Hou D, Zhu L, Xu W, Ding L, Qi X, Sun G, Liu C, Zhang J et al. 2010 17beta-estradiol inhibits oleic acid-induced rat VSMC proliferation and migration by restoring PGC-lalpha expression. Molecular and Cellular Endocrinology 315 74-80.

Kaminska B 2005 MAPK signalling pathways as molecular targets for anti-inflammatory therapy - from molecular mechanisms to therapeutic benefits. Biochimica et Biophysica Acta 1754 253-262.

Kiechl S, Lorenz E, Reindl M, Wiedermann CJ, Oberhollenzer F, Bonora E, Willeit J \& Schwartz DA 2002 Toll-like receptor 4 polymorphisms and atherogenesis. New England Journal of Medicine 347 185-192.

Kublickiene K, Fu XD, Svedas E, Landgren BM, Genazzani AR \& Simoncini T 2008 Effects in postmenopausal women of estradiol and medroxyprogesterone alone and combined on resistance artery function and endothelial morphology and movement. Journal of Clinical Endocrinology and Metabolism 93 1874-1883.

Kyriakis JM \& Avruch J 2001 Mammalian mitogen-activated protein kinase signal transduction pathways activated by stress and inflammation. Physiological Reviews 81 807-869.

Laman JD, Schoneveld AH, Moll FL, van Meurs M \& Pasterkamp G 2002 Significance of peptidoglycan, a proinflammatory bacterial antigen in atherosclerotic arteries and its association with vulnerable plaques. American Journal of Cardiology 90 119-123.

Lee EY, Chung CH, Khoury CC, Yeo TK, Pyagay PE, Wang A \& Chen S 2009 The monocyte chemoattractant protein-1/CCR2 loop, inducible by TGF-beta, increases podocyte motility and albumin permeability. American Journal of Physiology. Renal Physiology 297 F85-F94.

Lehr HA, Sagban TA, Ihling C, Zahringer U, Hungerer KD, Blumrich M, Reifenberg K \& Bhakdi S 2001 Immunopathogenesis of atherosclerosis: endotoxin accelerates atherosclerosis in rabbits on hypercholesterolemic diet. Circulation 104 914-920. 
Lianxu C, Hongti J \& Changlong Y 2006 NF-kappaBp65-specific siRNA inhibits expression of genes of COX-2, NOS-2 and MMP-9 in rat IL-1beta-induced and TNF-alpha-induced chondrocytes. Osteoarthritis and Cartilage 14 367-376.

Liao W 1996 Endotoxin: possible roles in initiation and development of atherosclerosis. Journal of Laboratory and Clinical Medicine 128 452-460.

Lin SJ, Lee IT, Chen YH, Lin FY, Sheu LM, Ku HH, Shiao MS, Chen JW \& Chen YL 2007 Salvianolic acid B attenuates MMP-2 and MMP-9 expression in vivo in apolipoprotein-E-deficient mouse aorta and in vitro in LPS-treated human aortic smooth muscle cells. Journal of Cellular Biochemistry 100 372-384.

Liu HB, Loo KK, Palaszynski K, Ashouri J, Lubahn DB \& Voskuhl RR 2003 Estrogen receptor alpha mediates estrogen's immune protection in autoimmune disease. Journal of Immunology 171 6936-6940.

Liu R, Moroi M, Yamamoto M, Kubota T, Ono T, Funatsu A, Komatsu H, Tsuji T, Hara H, Hara $\mathrm{H}$ et al. 2006 Presence and severity of Chlamydia pneumoniae and cytomegalovirus infection in coronary plaques are associated with acute coronary syndromes. International Heart Journal 47 511-519.

Liu HM, Zhao XF, Guo LN, Tan Z \& Wang TH 2007 Effects of caveolin-1 on the 17beta-estradiol-mediated inhibition of VSMC proliferation induced by vascular injury. Life Sciences $\mathbf{8 0} 800-812$.

Liu CJ, Lo JF, Kuo CH, Chu CH, Chen LM, Tsai FJ, Tsai CH, Tzang BS, Kuo WW \& Huang CY 2009 Akt mediates 17beta-estradiol and/or estrogen receptor alpha inhibition of LPS-induced tumor necrosis factor-alpha expression and myocardial cell apoptosis by suppressing the JNK1/2-NFkappaB pathway. Journal of Cellular and Molecular Medicine 13 3655-3667.

Loppnow H, Werdan K \& Buerke M 2008 Vascular cells contribute to atherosclerosis by cytokine- and innate-immunity-related inflammatory mechanisms. Innate Immunity 14 63-87.

Lu ZY, Jensen LE, Huang Y, Kealey C, Blair IA \& Whitehead AS 2009 The up-regulation of monocyte chemoattractant protein-1 (MCP-1) in Ea.hy 926 endothelial cells under long-term low folate stress is mediated by the p38 MAPK pathway. Atherosclerosis 205 48-54.

Ma J, Wang Q, Fei T, Han JD \& Chen YG 2007 MCP-1 mediates TGF-beta-induced angiogenesis by stimulating vascular smooth muscle cell migration. Blood 109 987-994.

Mendelsohn ME \& Karas RH 1999 The protective effects of estrogen on the cardiovascular system. New England Journal of Medicine $\mathbf{3 4 0}$ 1801-1811.

Polanczyk M, Zamora A, Subramanian S, Matejuk A, Hess DL, Blankenhorn EP, Teuscher C, Vandenbark AA \& Offner H 2003 The protective effect of 17beta-estradiol on experimental autoimmune encephalomyelitis is mediated through estrogen receptor-alpha. American Journal of Pathology 163 1599-1605.

Pozzi S, Benedusi V, Maggi A \& Vegeto E 2006 Estrogen action in neuroprotection and brain inflammation. Annals of the New York Academy of Sciences 1089 302-323.

Ross R 1999 Atherosclerosis is an inflammatory disease. American Heart Journal 138 S419-S420.

Rossouw JE, Anderson GL, Prentice RL, LaCroix AZ, Kooperberg C, Stefanick ML, Jackson RD, Beresford SA, Howard BV, Johnson KC et al. 2002 Risks and benefits of estrogen plus progestin in healthy postmenopausal women: principal results from the Women's Health Initiative randomized controlled trial. Journal of the American Medical Association 288 321-333.

Rossouw JE, Prentice RL, Manson JE, Wu L, Barad D, Barnabei VM, Ko M, LaCroix AZ, Margolis KL \& Stefanick ML 2007 Postmenopausal hormone therapy and risk of cardiovascular disease by age and years since menopause. Journal of the American Medical Association 297 1465-1477.

Rovin BH, Dickerson JA, Tan LC \& Hebert CA 1995 Activation of nuclear factor-kappa B correlates with MCP-1 expression by human mesangial cells. Kidney International 48 1263-1271.
Ryan S, McNicholas WT \& Taylor CT 2007 A critical role for p38 map kinase in NF-kappaB signaling during intermittent hypoxia/reoxygenation. Biochemical and Biophysical Research Communications 355 728-733.

Shrum CK, Defrancisco D \& Meffert MK 2009 Stimulated nuclear translocation of NF-kappaB and shuttling differentially depend on dynein and the dynactin complex. PNAS 106 2647-2652.

Simoncini T, Scorticati C, Mannella P, Fadiel A, Giretti MS, Fu XD, Baldacci C, Garibaldi S, Caruso A, Fornari L et al. 2006 Estrogen receptor alpha interacts with Galpha13 to drive actin remodeling and endothelial cell migration via the RhoA/Rho kinase/moesin pathway. Molecular Endocrinology 20 1756-1771.

Smith BJ, Lightfoot SA, Lerner MR, Denson KD, Morgan DL, Hanas JS, Bronze MS, Postier RG \& Brackett DJ 2009 Induction of cardiovascular pathology in a novel model of low-grade chronic inflammation. Cardiovascular Pathology 18 1-10.

Speyer CL, Rancilio NJ, McClintock SD, Crawford JD, Gao H, Sarma JV \& Ward PA 2005 Regulatory effects of estrogen on acute lung inflammation in mice. American Journal of Physiology. Cell Physiology 288 C881-C890.

Spinetti G, Wang M, Monticone R, Zhang J, Zhao D \& Lakatta EG 2004 Rat aortic MCP-1 and its receptor CCR2 increase with age and alter vascular smooth muscle cell function. Arteriosclerosis, Thrombosis, and Vascular Biology 24 1397-1402.

Tiruppathi C, Shimizu J, Miyawaki-Shimizu K, Vogel SM, Bair AM, Minshall RD, Predescu D \& Malik AB 2008 Role of NF-kappaBdependent caveolin-1 expression in the mechanism of increased endothelial permeability induced by lipopolysaccharide. Journal of Biological Chemistry 283 4210-4218.

Vegeto E, Belcredito S, Etteri S, Ghisletti S, Brusadelli A, Meda C, Krust A, Dupont S, Ciana P, Chambon P et al. 2003 Estrogen receptor-alpha mediates the brain antiinflammatory activity of estradiol. PNAS 100 9614-9619.

Wang G, Siow YL \& Karmin O 2000 Homocysteine stimulates nuclear factor kappaB activity and monocyte chemoattractant protein-1 expression in vascular smooth-muscle cells: a possible role for protein kinase C. Biochemical Journal 352 817-826.

Wiedermann CJ, Kiechl S, Dunzendorfer S, Schratzberger P, Egger G, Oberhollenzer F \& Willeit J 1999 Association of endotoxemia with carotid atherosclerosis and cardiovascular disease: prospective results from the Bruneck Study. Journal of the American College of Cardiology 34 1975-1981.

Wu J, Gong J, Geng J \& Song Y 2008 Deoxycholic acid induces the overexpression of intestinal mucin, MUC2, via NF-kB signaling pathway in human esophageal adenocarcinoma cells. BMC Cancer 8333.

Xing D, Feng W, Miller AP, Weathington NM, Chen YF, Novak L, Blalock JE \& Oparil S 2007 Estrogen modulates TNF-alpha-induced inflammatory responses in rat aortic smooth muscle cells through estrogen receptor-beta activation. American Journal of Physiology. Heart and Circulatory Physiology 292 H2607-H2612.

Yang X, Coriolan D, Murthy V, Schultz K, Golenbock DT \& Beasley D 2005 Proinflammatory phenotype of vascular smooth muscle cells: role of efficient Toll-like receptor 4 signaling. American Journal of Physiology. Heart and Circulatory Physiology 289 H1069-H1076.

Yasui T, Saijo A, Uemura H, Matsuzaki T, Tsuchiya N, Yuzurihara M, Kase Y \& Irahara M 2009 Effects of oral and transdermal estrogen therapies on circulating cytokines and chemokines in postmenopausal women with hysterectomy. European Journal of Endocrinology 161 267-273.

Yuan Y, Shimizu I, Shen M, Aoyagi E, Takenaka H, Itagaki T, Urata M, Sannomiya K, Kohno N, Tamaki K et al. 2008 Effects of estradiol and progesterone on the proinflammatory cytokine production by mononuclear cells from patients with chronic hepatitis C. World Journal of Gastroenterology 14 2200-2207.

Received in final form 5 May 2010

Accepted 9 June 2010

Made available online as an Accepted Preprint 10 June 2010 